\title{
Study on the Strategies to Improve English Teachers' Pragmatic Competence
}

\author{
Haosheng $\mathrm{Xu}^{1, \mathrm{a}}$ and $\mathrm{Ru} \mathrm{Guo}^{2, \mathrm{~b}}$ \\ ${ }^{1}$ Xi'an University of Arts and Science, Xi'an, China 710065 \\ ${ }^{2}$ Xiguang Middle School, Xi'an, China 710000 \\ akatherine1972@126.com, bguoru0822@163.com
}

Keywords: Pragmatic competence; English teachers; Ongoing education; Pragmatic training

\begin{abstract}
In this study, we have determined the goal of training content of teacher's ongoing education by defining the concept of pragmatic ability in the context of improving the pragmatic competence of middle school English teachers. Taking the "Request Speech Act" as an example, we drew up the "ongoing education pragmatic training" program and tested the effectiveness of the training program. The study showed that this program had a positive effect on the improvement of English teachers' English pragmatic competence.
\end{abstract}

\section{The Raising of Question}

In the Chinese EFL environment, English teachers' classroom discourse is an important language material for students to learn. However, most of the English teachers in English are in the growth of inter language or intermediate language, they will often appear the problem of pragmatic failure which to some extent hinders the achievement of the general goal of the basic education stage.

The purpose of this study is to develop the "pragmatic training of continuing education "program in order to improve the teachers' English pragmatic competence, and to verify the effectiveness of the training program.

\section{Definition of Concept}

Different researchers have different definitions of pragmatic competence, such as Leech (1983: 10-14), Thomas (1983: 91-112), Bachman (1990: 85-98), Jung(2002:1-35), He Ziran (2004: 167), Chen Xinren (2009: 204) and so on .Although the researchers all have focused on the presentation of pragmatic competence, these definitions and descriptions are related to three factors: speech act, context and Appropriateness.

Lu Jiawei (2013: 67) defined the pragmatic competence as within the cognitive framework. "Pragmatic competence in verbal communication, the speaker through a certain cognitive processing can recognize the current context, and get the pragmatic knowledge stored in the long-term memory, so that a series of responses to the right words are produced, which includes 3 parts: pragmatic knowledge, pragmatic awareness and pragmatic performance" The author believes that the definition of the implementation of pragmatic training has a guiding significance in the operational level. Among them, the pragmatic knowledge is involved in the grasp of speech act and meta pragmatic knowledge, Pragmatic awareness is related to contextual variables of field, tenor mode (Halliday \& Hasan, 1985: 12), Pragmatic expression including appropriate speech acts and correct understanding. Therefore, the content of the "pragmatic training program of continuing education" consists of three parts: Meta pragmatic knowledge learning; speech act research and reflection induction.

\section{Research and Design}

The Research Problem. In this study, using the pre - post test design, through the preliminary investigation and a period of six months of training and monitoring, to test " effectiveness of continuing education pragmatic training" program. 
Object of Study. 20 English teachers in several key middle school of Shaanxi province were randomly selected as the experience group, and 10 of them were randomly; assigned to the experimental group"; The other 10 are in the control group and do not receive any pragmatic training.

Before the training experiment, the experiment group and control group were tested with PETS3 simulation. The average scores of PETS-3 in the experimental group and control group were all higher than 75, the t test results of independent samples (Table 1) showed that the difference between the two groups was not significant $(\mathrm{t} 18=0.50, \mathrm{p}>0.05)$, which shows that the English language level of the experimental group and the control group is homogeneous. Samples were statistically analyzed (Table 2), the average score of 20 teachers was significantly greater than 75 points $(\mathrm{t} 19=6.25, \mathrm{P}<0.001)$, the two groups were all tested with good English language skills.

Table 1 Comparing differences of PETS-3 scores (M (SD))in experimental group and control

\begin{tabular}{|l|l|l|l|l|}
\multicolumn{5}{c|}{ group } \\
\hline & $\begin{array}{l}\text { experience } \\
\text { group }\end{array}$ & Control group & t & p \\
\hline $\mathrm{M}(\mathrm{SD})$ & $79.60(3.13)$ & $78.90(3.07)$ & 0.50 & 0.620 \\
\hline
\end{tabular}

Table 2 PETS-3 scores (M (SD)) statistics

\begin{tabular}{|l|l|l|l|l|}
\hline & $\mathrm{N}$ & $\mathrm{M}(\mathrm{SD})$ & $\mathrm{t}$ & $\mathrm{p}$ \\
\hline PETS-3 & 20 & $79.25(3.04)$ & 6.25 & 0.000 \\
\hline
\end{tabular}

Pragmatic Training Program. Training content and tools; Speech act as one of the main indicators of pragmatic competence is listed as the main training content. The training project of this research is "request" speech acts; Training materials for the new pragmatics tutorial "(Chen Xinren, foreign language teaching and Research Press, 2009) and the new pragmatic summary" (Firth. Shanghai: Shanghai Foreign Language Education Press, 2005); Training resources are "Wanfang Chinese Dissertations Database", "Chinese HowNet" and the internet; Training requirements for the collection, classification and analysis of the "request" speech act; Training methods focus on independent research, supplemented by meta pragmatic knowledge teaching; Training period is 20 weeks; training results in the form of a reading notes, a study report and more than 12 "request" speech act card.

Training process; the first stage: classroom teaching. The experimental group received the dominant classroom teaching of meta pragmatic knowledge, with a total of 12 hours teaching. The teaching content are: 1 meaning and context; 2 the meaning and category of instructions; 3 the theory of speech acts and the language of the indirect; 4 conversational implication and cooperative principle;5 relevance theory and relevance reasoning;6 politeness principles and strategies. Teaching model uses the second language pragmatic acquisition of classroom teaching mode put forward by Dai Weidong and Yang Xianju (2005). Using the four teaching steps of meta language knowledge to teach, simulating the true context, completing the communication task and evaluating and feedback.

The second stage: self-studying. Self-studying tested for 12 weeks requires that: 1 with the two specified materials ("new written pragmatic tutorial" and" new written pragmatics pragmatics"), do reading notes. 2 collect "request" speech acts from film and television, text, and make each request speech act into a card (card format as shown in Table 3).3 on the back of the card with details of the context, including the field of language (field), tenor (Tenor) and language style (mode), relating to the occasion, purpose, subject, the identity of the main body of communication and the relationship between them and the way of communication, what's more combine context to explain the rationality of the original speech act strategy. And determine the expression types of the speech acts, such as tone derived type, verbs sype, careful application for verbs and obligations stated type, 
demand representation, suggest expression, inquire about the type or implication. (Peng Yuan, 2012:133)

The third stage: Reflection report. In the last four weeks, they need to write no less than 5000 words of the reflective report for "request" speech acts, the content including: the literature summary, the request strategy, the specific expression type, the influencing factors and examples to illustrate the relationship between "request" speech act and politeness.

Table 3 An example of a request speech act card

\begin{tabular}{|l|l|l|l|}
\hline Content & $\begin{array}{l}\text { keep an eye on the } \\
\text { tier for me }\end{array}$ & Source & $\begin{array}{l}\text { Prison Break (TV } \\
\text { series })\end{array}$ \\
\hline steps & $\begin{array}{l}\text { Starting behavior } \\
\text { language(alerers) }\end{array}$ & $\begin{array}{l}\text { Auxiliary behavior } \\
\text { language(supportives) }\end{array}$ & $\begin{array}{l}\text { Key behavior } \\
\text { language(head } \\
\text { acts) }\end{array}$ \\
\hline $\begin{array}{l}\text { Direct speech act } \\
\text { the lines in the } \\
\text { play) }\end{array}$ & $\begin{array}{l}\text { Sucre, What are } \\
\text { you doing? }\end{array}$ & Will you? & $\begin{array}{l}\text { keep an eye on the } \\
\text { tier for me. }\end{array}$ \\
\hline Indirect reduction & Hi, Sucre, & $\begin{array}{l}\text { We're getting out of } \\
\text { here. }\end{array}$ & $\begin{array}{l}\text { Would you mind } \\
\text { keeping ...for me }\end{array}$ \\
\hline Indirect reduction & Well, Sucre, & $\begin{array}{l}\text { 'm trying making the } \\
\text { way out. }\end{array}$ & $\begin{array}{l}\text { Would you mind } \\
\text { keeping ...for me }\end{array}$ \\
\hline
\end{tabular}

Testing Tools and Data Collection. The test instrument is divided into three parts, each part of the test scores are 100 points, the first part is multinomial choice language discourse completion test (MDCT).This questionnaire with total of 20 questions is selected from MDCT Test Paper of Liu(2006), this part of the weight of 0.25 is used to measure pragmatic knowledge. The second part uses the written discourse to complete test to complete the 10 incomplete dialogues, the weight of this part is 0.4 is used to investigate the pragmatic performance of the subjects; the three part is the result of the weighted average of the score as pragmatic competence score. A total of 3 questionnaires were administered for 120 minutes and allowed to look up the dictionary. After the end, the test paper and answer sheet all are recovered. The interval between the pre and post tests was 20 weeks. All the data are input to SPSS 17 for analysis and processing.

\section{Results and Analysis}

Per-test Results. Before the start of the study, we compared the results of the previous test scores (see Table 4) and found that the experimental group and the control group have differences in the pragmatic knowledge $(\mathrm{t} 18=1.09, \mathrm{p}>0.05)$, the pragmatic aware $(\mathrm{t} 18=0.35, \mathrm{p}>0.05)$, the pragmatic expression $(\mathrm{t} 18=0.82, \mathrm{p}>0.05)$ and the pragmatic ability $(\mathrm{t} 18=0.17, \mathrm{p}>0.05)$. Statistical analysis of the results of the previous test scores (see Table 5) showed that the average score of each part was significantly lower than 70 points (TS $>6, \mathrm{P}<0.001$ ), far below the level of their language performance.

The results of the previous test show that the subjects selected in this study are homogeneous, which can be used to compare with the experimental results. 
Table 4 The pre test scores (M (SD))of pragmatic ability of the experimental group and the control group and comparing the difference

\begin{tabular}{|l|l|l|l|l|}
\hline & Control group & $\begin{array}{l}\text { experience } \\
\text { group }\end{array}$ & $\mathrm{t}$ & $\mathrm{p}$ \\
\hline $\begin{array}{l}\text { Pragmatic } \\
\text { knowledge }\end{array}$ & $64.40(4.79)$ & $62.00(5.08)$ & 1.09 & 0.291 \\
\hline $\begin{array}{l}\text { Pragmatic } \\
\text { aware }\end{array}$ & $63.00(4.83)$ & $62.25(4.63)$ & 0.35 & 0.727 \\
\hline $\begin{array}{l}\text { Pragmatic } \\
\text { expression }\end{array}$ & $62.50(4.25)$ & $64.00(3.94)$ & 0.82 & 0.424 \\
\hline $\begin{array}{l}\text { Pragmatic } \\
\text { ability }\end{array}$ & $63.15(3.66)$ & $62.89(3.12)$ & 0.17 & 0.865 \\
\hline
\end{tabular}

Table 5 The pre test scores (M (SD)) statistics of the various pragmatic competence

\begin{tabular}{|l|l|l|l|l|}
\hline & $\mathrm{N}$ & $\mathrm{M}(\mathrm{SD})$ & $\mathrm{t}$ & $\mathrm{p}$ \\
\hline $\begin{array}{l}\text { Pragmatic } \\
\text { knowledge }\end{array}$ & 20 & $63.20(4.96)$ & 6.13 & 0.000 \\
\hline $\begin{array}{l}\text { Pragmatic } \\
\text { aware }\end{array}$ & 20 & $62.63(4.62)$ & 7.14 & 0.000 \\
\hline $\begin{array}{l}\text { Pragmatic } \\
\text { expression }\end{array}$ & 20 & $63.25(4.06)$ & 7.42 & 0.000 \\
\hline $\begin{array}{l}\text { Pragmatic } \\
\text { ability }\end{array}$ & 20 & $63.02(3.31)$ & 9.42 & 0.000 \\
\hline
\end{tabular}

Post Test Results. After the end of the "continuing education pragmatic training", the experiment group and control group did the post test. Difference between the result of the post test score comparison (Table 6) is, in the experimental group, the scores of pragmatic knowledge $(\mathrm{t} 18=3.24, \mathrm{P}<0.01)$ and pragmatic awareness $(\mathrm{t} 18=5.57, \mathrm{P}<0.001)$ were significantly higher than those in the control group. Although the difference between the two groups was not significant $(\mathrm{t} 18=0.94, \mathrm{P}>0.05)$, the experimental group pragmatic competence $(\mathrm{t} 18=4.13, \mathrm{P}<0.01)$ overall score was significantly higher than the control group. The results showed that the experimental treatment did result in the differences between the experimental group and control group, and the "continuing education pragmatic training" had a positive effect.

Table 6 The post test scores (M (SD)) between the experimental group and the control group. and the differences comparing

\begin{tabular}{|l|l|l|l|l|}
\hline & $\begin{array}{l}\text { Control } \\
\text { group }\end{array}$ & $\begin{array}{l}\text { experience } \\
\text { group }\end{array}$ & $\mathrm{t}$ & $\mathrm{p}$ \\
\hline $\begin{array}{l}\text { Pragmatic } \\
\text { knowledge }\end{array}$ & $64.40(4.79)$ & $72.00(5.66)$ & 3.24 & 0.005 \\
\hline $\begin{array}{l}\text { Pragmatic } \\
\text { aware }\end{array}$ & $63.00(4.83)$ & $73.75(4.45)$ & 5.57 & 0.000 \\
\hline $\begin{array}{l}\text { Pragmatic } \\
\text { expression }\end{array}$ & $63.00(4.83)$ & $65.00(4.71)$ & 0.94 & 0.361 \\
\hline $\begin{array}{l}\text { Pragmatic } \\
\text { ability }\end{array}$ & $63.40(3.40)$ & $69.81(3.53)$ & 4.13 & 0.001 \\
\hline
\end{tabular}


Comparison of Pre - and Post Test Results. The results of pre - and posttest were paired sample t test to control group and experimental group, the results (see Table 7) shows: In the control group, no significant difference was found in pragmatic knowledge, pragmatic awareness, pragmatic performance and pragmatic competence (ts $<1, \mathrm{p}>0.05$ ). This shows that, in the two language environment, there is no pragmatic teaching or training intervention, learners can not automatically acquire pragmatic competence

Table 7 The pre - and post test scores (M (SD)) of each part of the pragmatic competence of the control group and difference comparison

\begin{tabular}{|l|l|l|l|l|}
\hline & Pre-test & Post test & $\mathrm{t}$ & $\mathrm{p}$ \\
\hline $\begin{array}{l}\text { Pragmatic } \\
\text { knowledge }\end{array}$ & $64.40(4.79)$ & $64.40(4.79)$ & 0.00 & 1.000 \\
$\begin{array}{l}\text { Pragmatic } \\
\text { aware }\end{array}$ & $63.00(4.83)$ & $63.15(4.06)$ & 0.07 & 0.946 \\
$\begin{array}{l}\text { Pragmatic } \\
\text { expression } \\
\begin{array}{l}\text { Pragmatic } \\
\text { ability }\end{array}\end{array}$ & $62.50(4.25)$ & $63.00(4.83)$ & 0.32 & 0.758 \\
\hline
\end{tabular}

In order to investigate the training effect of the experimental group, the differences between the pre - and post test scores were compared, and the results showing. In experimental group, the pragmatic knowledge $(\mathrm{t} 9=7.32, \mathrm{P}<0.001)$, pragmatic awareness $(\mathrm{t} 9=17.25, \mathrm{P}<0.001)$ and pragmatic competence $(\mathrm{t} 9=11.69, \mathrm{P}<0.001)$ on the post test scores were significantly higher than pretest scores, but the differences in pragmatic performance is not significant $(\mathrm{t} 9=1.50, \mathrm{P}>0.05)$.

The experimental results show that, after the experimental treatment, the experimental group's pragmatic knowledge and pragmatic awareness level has been significantly improved which shows that the production of speech act cards can help the teachers to recognize the context, increase pragmatic knowledge, enhance pragmatic awareness, and thus grasp the speech act. Moreover, the "continuing education pragmatic training" program is effective in improving the overall pragmatic competence of middle school English teachers. But the training does not have a positive effect on the pragmatic performance, and further research and improvement should be done. The experiment also proved that, compared to the acquisition of pragmatic knowledge and pragmatic awareness, it is more difficult to improve the pragmatic performance, and the pragmatic knowledge and pragmatic awareness may also need to be more pragmatic in the real context.

Table 8 The each part pre - and post test scores (M (SD))of the pragmatic competence of the experimental group and differences comparing

\begin{tabular}{|l|l|l|l|l|}
\hline & Pre-test & Post test & $\mathrm{t}$ & $\mathrm{p}$ \\
\hline $\begin{array}{l}\text { Pragmatic } \\
\text { knowledge }\end{array}$ & $62.00(5.08)$ & $72.00(5.66)$ & 7.32 & 0.000 \\
\hline $\begin{array}{l}\text { Pragmatic } \\
\text { aware }\end{array}$ & $62.25(4.63)$ & $73.75(4.45)$ & 17.25 & 0.000 \\
\hline $\begin{array}{l}\text { Pragmatic } \\
\text { expression }\end{array}$ & $64.00(3.94)$ & $65.00(4.71)$ & 1.50 & 0.168 \\
\hline $\begin{array}{l}\text { Pragmatic } \\
\text { ability }\end{array}$ & $62.89(3.12)$ & $69.81(3.53)$ & 11.69 & 0.000 \\
\hline
\end{tabular}

\section{Conclusion}

This study is taking the "request" speech act as the subject, and draw up the program of "ongoing education pragmatic training" for middle school English teachers. The study shows that this 
approach has a positive effect on improving the pragmatic competence of middle school English teachers. The training strategy of "face to face teaching - self-studying - rethinking" conforms to the professional practice and cognitive characteristics of middle school teachers. However, there is still a significant defect in the program- no significant positive effect on the pragmatic performance of the trainees, and the reason remains to be further studied. At present, the existing problems reflected in the design and implementation of the program are: 1 . the speech act cards produced by the trainees are not timely corrected, so they cannot get timely feedback, which is not conducive to the diagnosis and improvement. 2 In the stage of self-training, there is no exchange between the trainees and no chance of verbal communication practice which cannot highlight the problem in the communication situation. 3, No reading question, no standard, no clear request for reading notes result in the trainees' superficial and perfunctory self-study. Aiming at these problems, the next step of research is to design and develop the online training courses, which is supposed to solve the above problems in the present study by taking advantage of the instantness, openness and cooperativeness of networks.

\section{Acknowledgements}

Project source: Research on the current situation and promotion strategy of the pragmatic competence of middle school English teachers in Shaanxi Province, the major theoretical and practical issues of social sciences" Item number 2013C089

\section{References}

[1] Bachman, L.F. Fundamental Considerations in Language Testing. Oxford; OUP, 1990.

[2] Halliday, M.A.K. \& R. Hasan. Language, Context, and Text: Aspects of Language in a Social-semiotic Perspective. Geelong: Deakin University Press, 1985.

[3] Jung, J. Issues in acquisitional pragmatics. TESOL and Applied Linguistics, 2002, (2):1-34.

[4] Leech, G. Principles of Pragmatics. London: Longman. 1983.

[5] Liu, J. Measuring Interlanguage Pragmatic Knowledge of EFL Learners. Frankfurt am Main: Peter Lang, 2006.

[6] Thomas, J. Cross-cultural pragmatic failure. Applied Linguistics. 1983, (4):91-112.

[7] Chen Xinren. A new pragmatic tutorial. Beijing: foreign language teaching and Research Press, 2009.

[8] Dai Weidong, Yang Xianju. Classroom teaching mode of Second Language Pragmatic Acquisition. Foreign Language Community, 2005, (1): 2-8.

[9] He Ziran. Pragmatics and English learning. Shanghai: Shanghai foreign language education press, 1997.

[10] He Ziran, Chen Xinren. current pragmatics. Beijing: foreign language teaching and Research Press, 2004.

[11] Jiang Zhanhao, Zhou Bao. The study of learners' pragmatic competence assessment. Foreign language teaching, 2012, (5): 46-47

[12]LuJiawei. The effect of classroom instruction on the development of learners' pragmatic competence in the cognitive framework of cognitive framework Chinese. Journal of PLA Foreign Languages Institute, 2013, (1): 67

[13]Peng Yuan. Interlanguage pragmatic study of the speech act of request. Journal of Huazhong Agricultural University (SOCIAL SCIENCE EDITION), 2012, (1): 132-136 